\title{
Wacana Khotbah Jumat di Surakarta: Suatu Kajian Linguistik Kultural
}

\author{
Kundharu Saddhono \\ email: kundharu@uns.ac.id, Fakultas Keguruan dan IImu Pendidikan, UNS \\ I Dewa Putu Wijana, \\ Fakultas IImu Budaya, UGM
}

\begin{abstract}
Abstrak: Khotbah Jumat merupakan salah satu sarana yang digunakan umat Islam yang bertujuan untuk mengajak masyarakat untuk berbuat baik dan mencegah perbuatan buruk (sarana dakwah). Seorang yang menyampaikan dakwah disebut khotib. Agar dapat menarik simpati dari jemaah atau orang yang menyimak khotbah, diperlukan sebuah keterampilan berbicara yang baik. Istilah untuk menarik massa malalui keterampilan berbicara dimaknai sebagai retorika. Di dalam khotbah Jumat banyak terdapat aspek bahasa yang dipengaruhi oleh unsur kebudayaan setempat. Khotbah Jumat sebagai sebuah wacana tentunya dapat dianalisis dari aspek mikrostruktural yang berkaitan dengan aspek gramatikal, aspek leksikal, kohesi, dan koherensi. Adapun dari aspek makrostruktural berkaitan dengan unsur kebudayaan atau kultural masyarakat sekitar di luar aspek kebahasaan atau linguistik yang di dalamnya berkaitan dengan konteks yaitu partisipan, tempat dan waktu, saluran yang digunakan, kode yang digunakan, bentuk pesan beserta isinya, peristiwa dengan sifat, dan nada pembicaraan.
\end{abstract}

Kata Kunci: wacana, khotbah Jumat, khotib, linguistik kultural, kebudayaan, dan Surakarta

\begin{abstract}
Abstrcat: Friday sermon is a means of religious endeavor used by Moslems to invite the community to do good things and avoid bad deeds. A person who conveys Friday sermon is called a preacher. A good speaking skill is needed in order to attract sympathy from the congregation or the people who listen to the sermon. The term 'attract masses through speaking skill' is called as rhetoric. In Friday sermons there are many aspects of language which are influenced by local cultural elements. Friday sermons as a discourse of course, can be analyzed from micro structural aspects related to grammatical aspect, lexical aspect, cohesion, and coherence. The macro structural aspects related to culture or cultural elements surrounding communities outside of language or linguistic aspects in which the participants related to the context, place and time, the channel used, the code used, the form of a message and its contents, events with nature, and tone of conversation.
\end{abstract}

Key words: discourse, Friday sermons, preachers, cultural linguistic, cultural, and Surakarta

\section{Pendahuluan}

Variasi atau ragam bahasa merupakan salah satu bahasan pokok dalam studi linguistik. Munculnya variasi tersebut berdasarkan faktor-faktor yang berpengaruh di dalamnya. Siapa yang berbicara, kepada siapa berbicara, dalam suasana apa pembicaraan itu dilakukan, apa yang menjadi pokok pembicaraan dan apa tujuan pembicaraan, merupakan faktor-faktor yang sangat menentukan terjadinya pemakaian bahasa dalam masyarakat. Salah satu bentuk variasi bahasa adalah variasi berdasarkan segi pemakaiannya. Variasi bahasa berkenaan dengan penggunaannya, pemakaiannya, atau fungsinya ini disebut fungsiolek, ragam, atau register.
Bentuk regiter yang akan dibahas dalam tulisan ini adalah khotbah. Menurut Kamus Besar Bahasa Indonesia (Anton M. Moeliono, 2008: 498), khotbah berarti pidato (terutama yang menguraikan tentang agama). Kata khotbah berasal dari bahasa Arab khutbah artinya adddres, speech, harangue, oration 'amanat, pidato' (Baal-Baki, 1993: 515). Pada hakikatnya khotbah berarti sebuah wasiat untuk bertakwa kepada khalayak baik bentuknya janji kesenangan maupun ancaman kesengsaraan (Sabiq, tt: 291). Dalam agama Islam setidaknya ada 5 macam khotbah, yaitu khotbah Jumat, khotbah hari raya (Idul Fitri dan Idul Adha), khotbah Gerhana (kusuf dan khusuf), khotbah permintaan hujan (istisqa), dan khotbah nikah. 
Khotbah Jumat berbeda jika dibandingkan dengan khotbah yang lain. Hal ini seperti dinyatakan oleh Ma'ruf (1999: 3-4) dan Saddhono (2011) bahwa khotbah hari raya, khotbah gerhana, dan khotbah permintaan hujan disampaikan sesudah salat, sedangkan khotbah Jumat disampaikan sebelum salat. Khotbah Jumat juga berbeda dengan khotbah nikah jika dilihat dari hukumnya. Khotbah Jumat hukumnya wajib, sedangkan khotbah nikah hukumnya tidak wajib. Ini berarti jika khotbah ditiadakan nikahnya tetap sah, tetapi tidak untuk salat Jumat. Selain itu, khotbah nikah disampaikan untuk kedua mempelai tetapi khotbah Jumat disampaikan untuk seluruh jemaah salat Jumat. Hal lain yang menjadi ciri khas khotbah Jumat adalah sesuai dengan nama harinya sehingga akan senantiasa teratur peristiwanya dan lebih sering kejadiannya jika dibandingkan khotbah yang lain. Selain itu, jika diamati lebih cermat khotbah Jumat juga mempunyai keistimewaan yaitu terdiri dari dua bagian dan di antara kedua khotbah tersebut khotib menyelainya dengan duduk.

Khotbah Jumat yang dalam bahasa Arab adalah khutbatul-Jum'ah berarti Friday sermon 'nasihat atau wejangan hari Jumat' (Baal-Baki, 1993: 515). Khotbah Jumat berasal dari bahasa Arab yang artinya pidato, wejangan yang disampaikan khatib di masjid sebelum salat Jumat. Adapun isi tuturan yang ada dalam khotbah tidak lain merupakan ajakan khatib kepada jemaahnya untuk menjadi orang yang bertakwa. Dengan demikian, khotbah Jumat merupakan nasihat khatib 'orang yang berkhotbah' kepada jemaah sebagai mitra wicara di masjid yang dituturkan pada hari Jumat sebelum salat Jumat ditunaikan.

Berdasarkan hasil pengamatan penulis selama ini, khotbah Jumat di Kota Surakarta disampaikan setidaknya dengan empat bahasa pengantar, yaitu bahasa Jawa, bahasa Indonesia, bahasa Arab, dan bahasa Inggris. Akan tetapi pada praktiknya, bahasa-bahasa tersebut sering dipakai secara bersamaan walaupun hanya beberapa unsur saja. Bahasa Jawa pada umumnya digunakan di daerah perdesaan dan sebagian kecil di daerah perkotaan. Bahasa Indonesia pada umumnya digunakan di daerah perkotaan. Hal ini dikarenakan di daerah perkotaan jemaah salat Jumat berasal dari berbagai latar belakang, baik pendidikan, budaya, profesi, dan lain-lain. Khotbah Jumat yang mengunakan bahasa pengantar bahasa Arab terdapat di masjid-masjid tertentu. Akan tetapi, setelah salat Jumat selesai ada penjelasan mengenai isi khotbah dengan menggunakan bahasa Indonesia atau bahasa Jawa. Adapun khotbah Jumat dengan pengantar bahasa Inggris hanya terdapat di tempat-tempat tertentu, seperti di sebuah pondok pesantren modern yang memberlakukan english day di daerah Laweyan.

Fokus kajian studi ini adalah khotbah Jumat di Kota Surakarta. Pemilihan objek studi register khotbah Jumat ini berangkat dari suatu pemikiran bahwa bahasa yang digunakan dalam khotbah Jumat secara hipotesis mempunyai bentuk, fungsi dan karakteristik yang khas. Apabila diamati, khotbah Jumat sebagai sebuah wacana lisan mempunyai struktur yang khas. Khotbah Jumat dimulai dan diakhiri dengan salam yang lengkap, yaitu Assalamu'alaikum Warahmatullahi Wabarakatuh untuk salam pembuka dan Wassalamu'alaikum Warahmatullahi Wabarakatuh untuk salam penutup. Selain itu, struktur khotbah Jumat juga mempunyai bentuk yang khas, yaitu terdiri atas 2 khotbah dan masing-masing mempunyai struktur tersendiri. Struktur khotbah Jumat pertama terdiri dari mengucap mukaddimah (pembukaan) khotbah yang berisi bacaan hamdalah, dua kalimat syahadat, dan selawat Nabi, menyeru kepada jemaah agar meningkatkan takwa, menyampaikan isi atau materi khotbah yang diperkuat dengan data, fakta, analisis, sejarah, nash-nash Alquran serta hadis yang dikutip, membuat kesimpulan singkat dari uraian khotbah, menutup khotbah pertama dengan harapan dan doa. Adapun khotbah Jumat kedua dibuka dengan bacaan hamdalah, dua kalimat syahadat, dan selawat Nabi, berwasiat tentang takwa, memberi penekanan atau kesimpulan dari uraian khotbah pertama, dan membaca doa penutup bagi segenap muslimin dan muslimat (Syam, 2003: 33).

Khotbah Jumat sebagai suatu ritual agama Islam tentu tidak akan lepas dari bahasa Arab. Oleh karena itu, unsur-unsur bahasa Arab pasti akan selalu muncul dalam khotbah Jumat. Selain karena tuntutan rukun, khotbah Jumat juga karena konsep-konsep keagamaan itu sendiri. Hal 
lain yang mempengaruhi pemakaian bahasa dalam khotbah Jumat juga kondisi masyarakat sebagai jemaah Jumat atau pendengarnya. Berkaitan dengan hal itu maka faktor sosiokultural juga akan mempengaruhi khotib, orang yang memberikan khotbah, dalam pemakaian bahasanya. Jadi, selain aspek linguistiknya, aspek kebudayaan juga akan banyak mempengaruhi pemakaian bahasa dalam khotbah Jumat, apalagi di Kota Surakarta yang mempunyai latar belakang budaya Jawa yang cukup dominan.

Kajian dengan mengambil wacana khotbah Jumat di Kota Surakarta sebagai objeknya ini dapat dikaji dari berbagai aspek. Namun demikian, penulis hanya menfokuskan pada kajian yang bersifat linguistik kebudayaan, yaitu gabungan antara kajian linguistik dan kajian budaya. Secara umum rumusan masalahnya: 1) Apakah khotbah Jumat termasuk dalam sebuah wacana? 2) Bagaimanakah fenomena linguistik secara mikrostruktural dalam khotbah Jumat? dan 3) Bagaimanakah fenomena sosiokultural secara makrostruktural dalam khotbah Jumat?

\section{Kajian Literatur}

Dalam kajian analisis wacana terdapat dua pendekatan yaitu pendekatan mikrostruktural dan pendekatan makrostruktural. Pendekatan mikrostruktural melihat bahwa wacana dibentuk atas dua segi yaitu segi bentuk atau kohesif dan segi makna atau koheren. Dapat dijelaskan lebih lanjut bahwa segi bentuk merupakan struktur lahir dari bahasa yang mencakup aspek gramatikal, sedangkan segi makna adalah struktur batin bahasa yang mencakup aspek leksikal.

Aspek gramatikal dalam sebuah wacana berkaitan dengan aspek bentuk sebagai struktur lahir bahasa. Pemarkah aspek gramatikal terdiri atas empat macam yaitu pengacuan (referensi), penyulihan (substitusi), pelesapan (elipisis), dan perangkaian (konjungsi) (Sumarlam, 2008).

Pengacuan terdiri atas tiga jenis yaitu persona, demonstrativa, dan komparatif. Pengacuan persona meliputi persona pertama tunggal (aku, saya, hamba, ku-, -ku), persona pertama jamak (kami, kita, kami semua), persona kedua tunggal (kamu, anda, kau, -mu), persona kedua jamak (kamu semua, kalian), persona ketiga tunggal (ia, dia, -nya), persona ketiga jamak (mereka, mereka semua). Pengacuan demonstrativa meliputi pengacuan waktu kini (kini, sekarang, saat ini), waktu lampau (kemarin, dulu, yang lalu), waktu yang akan datang (besok, yang akan datang), netral (pagi, siang, malam, pukul 12) dan pengacuan tempat dekat dengan penutur (sini, ini), agak dekat (situ, itu), jauh (sana), menunjuk secara eksplisit (Solo, Yogya). Pengacuan yang lain adalah komparatif yaitu membandingkan dua hal atau lebih yang mempunyai kemiripan dari segi bentuk, wujud, sifat, watak, perilaku dan lai-lain (seperti, bagaikan, persis, sama dengan, laksana).

Penyulihan atau substitusi adalah salah satu kohesi gramatikal yang berupa penggantian satuan lingual tertentu (yang telah disebut) dengan satuan lingual yang lain. Substitusi meliputi nominal, verbal, frasal dan kalimat. Sebagai contoh adalah derajat $\rightarrow$ pangkat merupakan substitusi berupa kata benda dengan kata benda, sedangkan aku dan dia $\rightarrow>$ dua orang dalam kalimat aku dan dia saja yang pergi menjadi dua orang saja yang pergi merupakan substitusi yang berupa frasal dengan frasal. Substitusi ini mempunyai tujuan antara lain variasi bentuk, dinamisasi narasi, menghilangkan kemonotonan, dan memperoleh unsur pembeda.

Pelesapan atau elipsis adalah salah satu jenis kohesi gramatikal yang berupa penghilangan unsur (konstituen) tertentu yang telah disebutkan. Unsur yang dilesapkan bisa berupa kata, frasa, klausa atau kalimat (Kemarin Ibu membelikan aku sebuah baju. -ibu membelikan aku- Hari ini buku cerita). Dalam contoh tersebut kalimat ibu membelikan aku pada kalimat kedua dihilangkan. Fungsi pelesapan ini antara lain adalah kepraktisan, efektivitas kalimat, ekonomi bahasa (efisiensi), mencapai aspek kepaduan wacana, dan bagi pembaca untuk mengaktifkan pikirannya terhadap hal-hal yang tidak diungkapkan dalam satuan bahasa.

Perangkai atau konjungsi yaitu salah satu kohesi gramatikal yang dilakukan dengan cara menghubungkan unsur yang satu dengan unsur yang lain. Unsur yang dirangkai bisa berwujud kata, frasa, klausa, kalimat, alinea, dan topik pembicaraan. Pemarkah konjungsi bisa berupa sebab akibat (sebab, karena, maka), pertentangan (tetapi), kelebihan atau eksesif (malah), perkecualian atau ekseptif (kecuali), konsensif 
(walaupun, meskipun), tujuan (agar, supaya), penambahan atau aditif (dan, juga, serta), pilihan atau alternatif (atau, apa), harapan atau optatif (moga-moga, semoga), urutan atau sekuensial (lalu, terus, kemudian), perlawanan (sebaliknya), waktu (setelah, sesudah, selesai), syarat (jika, apabila), cara (dengan cara begitu), dan maknamakna yang lain.

Selain aspek gramatikal ada aspek yang lain yaitu aspek leksikal. Aspek leksikal atau kohesi leksikal yaitu hubungan antarunsur dalam wacana secara semantis. Kohesi leksikal meliputi pengulangan (repetisi), padan kata (sinonimi), sanding kata (kolokasi), hubungan atas-bawah (hiponimi), lawan kata (antonimi), dan kesepadanan atau paradigma (ekuivalensi)

Pendekatan yang kedua adalah pendekatan makrostruktural yaitu menitikberatkan pada susunan wacana tersebut secara global untuk memahami secara keseluruhan. Pendekatan makrostruktural dalam kajian ini meliputi konteks situasi yang mencakup prinsip penafsiran personal, prinsip penafsiran lokal, prinsip penafsiran temporal, prinsip analogi, dan inferensi. Selain pendekatan konteks situasi juga memperhatikan faktor sosial budaya. Pendekatan sosial budaya ini menggunakan faktor genetik yaitu kondisi yang bisa membentuk atau mengambil bagian di dalam proses pembentukan karya, yang meliputi kepribadian senimannya, kondisi psikologinya, seleranya, ketrampilannya, kemampuannya, pengalamannya, latar belakang sosial budayanya, dan juga berbagai peristiwa di sekitarnya yang bergayutan dengan proses penciptaan karya seni (Sutopo, 1996: 10).

\section{Metode Penelitian}

Penelitian ini mengkaji pemakaian bahasa khotbah Jumat berdasarkan konteks dan situasi. Jenis penelitian ini berbentuk deskriptif kualitatif dengan setting apa adanya (natural setting) yang pada dasarnya mendeskripsikan secara kualitatif dalam bentuk kata-kata dan bukan angka-angka matematis atau statistik (Lindlof, 1994: 21).

Populasi dalam kajian ini adalah khotbah Jumat di Kota Surakarta yang terdiri dari lima kecamatan dan lima lingkungan masjid, yaitu Jebres (lingkungan pendidikan), Laweyan (lingkungan keagamaan), Pasar Kliwon (lingkungan keluarga), Banjarsari (lingkungan jaringan kerja), dan Serengan (lingkungan sosial). Khotbah Jumat yang dijadikan sampel dalam studi ini adalah dalam kurun waktu 2008-2009. Wacana khotbah yang diambil sebagai sampel adalah data yang memiliki karakter sesuai data yang diinginkan penulis dan dianggap dapat mewakili populasi secara keseluruhan. Hal ini mengacu pendapat Subroto (2009: 32) bahwa sampel dalam penelitian merupakan sebagian dari populasi yang dijadikan objek penelitian. Teknik penarikan sampel yang digunakan dalam kajian ini adalah purposive sample.

Pengumpulan data dalam kajian ini menggunakan teknik rekam dan teknik catat. Adapun hal-hal yang perlu dicatat antara lain : 1) waktu dan tempat terjadinya peristiwa tutur; 2) wujud tuturan; 3 ) identitas penutur dan masyarakat tuturnya; dan 4) tujuan tuturan atau hal yang dituturkan (Saddhono, 2009:54). Pengumpulan data juga menggunakan teknik wawancara mendalam (indepth-interviewing) yang dilakukan pemberi khotbah Jumat atau khotib. Hal-hal yang ditanyakan dalam wawancara terkait dengan permasalahan dalam kajian yaitu bahasa khotbah Jumat.

Kajian ini menggunakan metode padan, yaitu teknik yang dipakai untuk mengkaji atau menentukan identitas satuan lingual tertentu dengan memakai alat penentu yang berada di luar bahasa, terlepas dari bahasa, dan tidak menjadi bagian dari bahasa yang bersangkutan (Sudaryanto, 1995: 13). Soepomo Poedjosoedarmo (dalam Maryono, 2001: 20) menyatakan bahwa penelitian linguistik, seperti penelitian wacana khotbah Jumat ini pada dasarnya adalah penelitian kontekstual. Penelitian kontekstual adalah penelitian mengenai wujud tuturan (bahasa) dengan memperhatikan konteks sosial yang menyertai terjadinya suatu tuturan. Dalam analisis data akan diperhitungkan konteks sosial yang berupa komponen tutur. Komponen tutur yang diperhitungkan dalam analisis data kajian ini yaitu: 1) penutur atau pembicara; 2) mitra tutur atau lawan tutur; 3) situasi tutur atau situasi bicara; 4) tujuan tuturan; dan 5) hal yang dituturkan. Hal ini menunjukkan bahwa analisis bahasa dalam penelitian ini dilakukan dengan memperhatikan unsur-unsur di luar bahasa, 
seperti faktor sosial, faktor situasional, dan faktor kultural (Markhamah, 2001: 11).

\section{Hasil Penelitian dan Pembahasan Khotbah sebagai Sebuah Wacana}

Wacana berdasarkan dari jumlah peserta yang terlibat dalam komunikasi dikenal adanya wacana monolog, dialog, dan polilog (Rani dkk., 2006: 25). Khotbah Jumat sebagai salah satu wacana lisan berdasarkan jumlah pesertanya dikategorikan sebagai wacana monolog. Hal ini dikarenakan yang terlibat dalam peristiwa tutur tersebut hanya satu, yaitu khotib atau yang memberikan khotbah. Walaupun yang terlibat dalam peristiwa tutur dalam khotbah Jumat tersebut banyak akan tetapi yang melakukan tuturan hanya satu orang. Mitra tutur dalam khotbah Jumat hanya mendengarkan dan merespon beberapa hal dari khotib atau penutur. Respon tersebut berupa menjawab salam dan mengaminin doa khotib. Berdasarkan fenomena tersebut, jelaslah bahwa khotbah Jumat termasuk wacana monolog.

Khotbah Jumat dikatakan sebagai wacana juga dinyatakan oleh Sumarlam (2008: 15) yang menjelaskan bahwa wacana adalah satuan bahasa terlengkap yang dinyatakan secara lisan seperti pidato, ceramah, khotbah, dan dialog, atau secara tertulis seperti cerpen, novel, buku, surat dan dokumen tertentu, yang dilihat dari struktur lahirnya (dari segi bentuk) bersifat kohesif, saling berkait dan dari struktur batinnya (dari segi makna) bersifat koheren, terpadu.

Bukti bahwa wacana khotbah Jumat termasuk wacana monolog adalah ketika ada pertanyaan yang disampaikan oleh khotib, jemaah khotbah Jumat tidak menjawab dan dijawab sendiri oleh khotib. Fenomena tersebut dapat dilihat pada data [1] di bawah ini.

Ketika kembali, ketika dipanggil, dan mati adalah untuk mempertanggungjawabkan dan untuk ditanyai dari nikmat yang diberikan. Sangunya apa? Ya kebaikan yang dilakukan itu.

Pada data [1] di atas terdapat kalimat pertanyaan "Sangunya apa?". Pertanyaan tersebut dituturkan oleh khotib kepada seluruh jemaah. Walaupun khotib bertanya tetapi sebenarnya tidak meminta jawaban dari jemaah sebagai mitra tutur. Akan tetapi tuturan tersebut sebagai tanda bahwa dalam peristiwa tutur tersebut, khotib dalam hal ini adalah penutur melibatkan jemaah sebagai mitra tutur untuk berinteraksi walaupun tidak secara langsung harus ditanggapi. Interaksi secara langsung yang jelas secara eksplisit melibatkan jemaah sebagai mitra tutur dalam peristiwa tutur adalah dengan pilihan kata "kita" yang digunakan oleh seluruh khotib dalam khotbahnya. Pemakaian kata "kita" terdeskripsi dalam data [2] sampai dengan [3] berikut ini.

[2] Kita wajib dan harus mensyukuri nikmat Allah agar kita semuanya men jadi hamba-hamba Allah yang selalu dicintai Allah.

[3] Karena itulah, maka adil kepada diri sendiri berarti bagaimana kita memberikan seluruh kebutuhan dari komponen-komponen dalam diri kita, baik fisik kita, rohani kita, maupun akal pikiran kita.

Tampak pada data [2] dan [3] yang menunjukkan bahwa ada sebuah tuturan yang melibatkan orang lain dengan munculnya kata "kita". Kita dalam Kamus Besar Bahasa Indonesia (2008: 506) mempunyai arti pronomina persona pertama jamak yang berbicara bersama dengan orang lain termasuk yang diajak bicara. Hal ini menunjukkan bahwa dalam tuturan tersebut melibatkan penutur yaitu khotib dan mitra tutur adalah jemaah salat Jumat.

Adanya kata "kita" menunjukkan bahwa komunikasi tersebut terjalin antara penutur dan mitra tutur. Djajasudarma (2009: 4) menyatakan bahwa dalam wacana baik lisan maupun wacana tulis selalu terdapat unsur penyapa (yang menyapa) dan pesapa (yang disapa). Diperjelas lagi bahwa apapun bentuknya, wacana mengasumsikan adanya penyapa (addressor) dan pesapa (addresse). Apabila wacana tersebut berbentuk lisan maka penyapa adalah pembicara atau penutur, sedangkan pesapa adalah pendengar atau mitra tutur. Adapun dalam wacana tulis, penyapa adalah penulis dan pesapa adalah pembaca. Dalam khotbah Jumat, yang dimaksud penyapa adalah khotib dan pesapa adalah jemaah salat Jumat.

Hal lain yang menunjukkan bahwa khotbah Jumat merupakan wacana adalah adanya salam ketika khotbah dimulai, yaitu assalâmu 'alaikum wa rahmatullâhi wa barakâtuh. Salam ini juga memperkuat bahwa ada komunikasi dua arah 
antara penutur dan mitra tutur. Salam tentu digunakan penutur untuk menyapa pada awal pertemuan dengan mitra tutur. Pada khotbah Jumat mintra tutur pun kemudian menjawab salam dari khotib dengan kalimat wassalâmu 'alaikum wa rahmatullâhi wa barakâtuh.

Ungkapan salam juga memberikan gambaran bahwa tuturan yang disampaikan oleh khotib adalah wacana yang lengkap. Khotbah Jumat adalah sebuah pidato yang berisi ajakan untuk bertakwa kepada Allah swt.. Dalam khotbah Jumat ada pembukaan, isi, dan penutup. Khotbah Jumat merupakan ungkapan kebahasaan yang selesai dan bermakna dimaksudkan sebagai kelompok kata atau gabungan kata, yang selesai dapat diartikan yang habis, yang tamat, yang berakhir, dan yang dimaksud bermakna yang mempunyai arti penting, dalam hal ini adalah wasiat takwa. Ini menunjukkan bahwa tuturan yang disampaikan khotib adalah sebuah wacana yang membicara satu tema wacana.

Khotbah Jumat dinyatakan sebagai sebuah bentuk wacana tidak hanya dikarenakan adanya saluran komunikasi yang berupa lisan dan adanya penutur dan mitra tutur. Namun, termasuk karena kepemilikan ciri adanya kohesi dan koherensi yang terdapat di dalam khotbah Jumat sehingga menyebabkan khotbah Jumat dikatakan sebagai sebuah wacana. Ciri kohesi maupun koherensi akan lebih jelas terlihat ketika sebuah khotbah Jumat ditranskrip terlebih dahulu dalam sebuah teks. Dari transkrip tersebut akan terlihat adanya keterkaitan antarproposisi yang mendukung sebuah pokok gagasan yang dilengkapi dengan adanya aspek gramatikal dan leksikal. Misalnya dalam sebuah paragraf transkrip khotbah Jumat di atas terdapat sebuah paragraf yang memaparkan mengenai makna sebuah kata "syukur". Kalimat-kalimat yang terangkai dalam paragraf tersebut mengacu pada satu penjelasan yaitu mengenai makna "syukur". Kemudian bentuk koherensi dalam khotbah Jumat di atas terbangun dari pengembangan topik-topik pembicaraan yang mengacu pada satu tema pembicaraan khotbah Jumat tersebut. Hal tersebut tampak jelas pada data [4] berikut ini.

[4] Ya, jemaah yang dirahmati Allah, marilah kita bersama-sama panjatkan syukur ke hadirat Allah subhanahu wataala, karena Allah telah memberikan berjuta-juta kenikmatan kepada kita sekalian, dan kenikmatan itu telah kita nikmati satu demi satu. Walaupun kadang kita lupa memohon, walaupun kadang kita lupa bersyukur kepada-Nya, maka tetaplah Allahu Akbar, Allah maha Besar. Subhanallah. Allah tetap memberikan kenikmatan itu kepada kita sekalian. Maka, kita wajib dan harus mensyukuri nikmat Allah agar kita semuanya menjadi hamba-hamba Allah yang selalu dicintai Allah. Hamba-hamba Allah yang dirindukan oleh zaman. Wainnallaha yuhibbul muttaqin. Sesungguhnya Allah mencintai hamba-hambaNya yang muttaqin, yaitu hamba-hamba-Nya yang melaksanakan perintah-perintahNya dan menjahui laranganlaranganNya.

Pada data [4] terlihat bahwa untuk mengekspresikan rasa syukur, penutur menggunakan banyak kata untuk menjelaskannya. Hampir seluruh paragraf dalam data [4] menjelaskan tentang rasa syukur kepada Allah swt.. Dalam data [4] kata 'syukur' muncul tiga kali. Bahkan untuk menjelaskannya secara implisit juga terdapat dalam tiap kalimat. Misalnya bentuk syukur dilakukan dengan cara seperti pada akhir paragraf yaitu 'hamba-hambaNya yang melaksanakan perintah-perintahNya dan menjahui larangan-laranganNya'. Pada tengah tuturan pun terlihat ekspresi syukur dengan kalimat Subhanallah yang menyiratkan rasa syukur seorang hamba kepada Allah swt.. Ekspresi yang lain adalah adanya kata Allahu Akbar sebagai wujud rasa syukur.

Keutuhan makna yang dimiliki khotbah Jumat dapat terjadi karena bagian-bagian di dalam suatu struktur yang saling berkaitan secara kohesif dan koheren antara satu dengan yang lainnya. Oleh karena hanya dalam kaitannya dengan keseluruhan dan keutuhan tersebut dapat dikaji unsur-unsurnya. Jadi, unsur-unsur itu hanya berarti dalam totalitas keseluruhannya. Kajian terhadap khotbah Jumat yang baik harus selalu mendudukkannya sebagai satu bangunan utuh dan tidak memenggal bagian-bagian khotbah Jumat itu sendiri. Pemahaman atas keutuhan makna sebagai satu kesatuan yang kohesif dan koheren berati meletakan terminologi bahwa khotbah Jumat adalah wacana. Hal ini dipertegas 
oleh pernyataan Harimurti Kridalaksana (2008: 208) dan Henry Guntur Tarigan (2009: 54) bahwa struktur wacana dipresentasikan oleh satuan bahasa yang lengkap, memiliki sifat kohesi dan koherensi yang tinggi, dalam hierarki gramatikal merupakan satuan gramatikal tertinggi dan terbesar. Wacana ini direalisasikan dalam bentuk karangan yang utuh (novel, puisi, buku, seri ensiklopedia, dan sebagainya) dengan paragraf, kalimat atau kata yang membawa amanat yang lengkap.

Wacana adalah satuan bahasa paling lengkap yang memiliki kohesi dan koherensi yang baik, mempunyai awal dan akhir yang jelas, berkesinambungan, dan dapat disampaikan secara lisan maupun tertulis (Tarigan, 2009: 27). Hal ini dipertegas oleh Crystal (1987: 96) bahwa wacana adalah suatu rangkaian bahasa (khususnya bahasa lisan) yang lebih luas daripada kalimat. Wacana dianggap sebagai sekelompok ujaran dari suatu peritiwa tutur yang dapat dikenali seperti percakapan, lelucon, pidato atau khotbah, dan wawancara. Wacana dalam pandangan ini diartikan sebagai ungkapan lisan atau dilisankan. Borwn dan Yule (1996: 9) menyatakan bahwa wacana terealiasasi dalam bentuk teks sehingga kata teks dipakai sebagai istilah teknis yang mengacu pada rekaman verbal tindak komunikasi. Adapun Halliday dan Hasan (1994: 13) berpendapat bahwa teks adalah bahasa yang berfungsi, artinya bahasa yang sedang melaksanakan tugas tertentu dalam konteks situasi tertentu pula. Jadi, teks adalah satuan bahasa yang memiliki keutuhan makna dan bersifat fungsional dan kontekstual. Teks sebagai realisasi wacana bukalah teks mati yang tidak memiliki ciri pemakaian, akan tetapi memiliki ciriciri suprasentential atau kelengkapan dan situasi pemakaian atau konteks yang berfungsi dan digunakan dalam komunikasi (Edmondson, 1981: 4; Schiffrin, 1984: 23-29). Hal ini tentu tergambar dalam khotbah Jumat yang merupakan sebuah wacana dan mempunyai makna yang utuh.

\section{Analisis Mikrostruktural}

Hubungan perkaitan antarproposisi yang dinyatakan secara eksplisit oleh unsur-unsur gramatikal dan semantik dalam kalimat-kalimat yang membentuk wacana. Di bawah ini akan dipaparkan mengenai aspek gramatikal dalam sebuah khotbah Jumat. Piranti wacana yang biasanya digunakan untuk mendukung kepaduan wacana dari segi aspek gramatikal meliputi pengacuan, elipsis, penyulihan, dan konjungsi.

Referensi atau pengacuan adalah hubungan antara referen yang ada di dunia luar bahasa dengan lambangnya di dalam dunia bahasa. Terdapat tiga jenis referensi dalam wacana yaitu pengacuan persona, demonstratif dan komparatif. Namun, dalam analisis khotbah ini, hanya terdapat dua penggunaan pengacuan yaitu pengacuan persona dan demonstratif.

[5] Puji syukur senantiasa kita panjatkan kehadirat Allah swt. yang telah berkenan memberikan berbagai kenikmatan kepada kita semua sehingga atas pemberian tersebut kita dapat melaksanakan aktivitas seperti yang kita inginkan dan dapat pula kita sampaikan sebagai rasa syukur kita kehadirat Allah swt. dengan memperbanyak ibadah dan dzikir kepada Allah.

Pada kalimat [5] terdapat pengacuan persona pertama jamak yaitu dengan digunakannya pronomina kita yang berarti persona pertama (khotib) melibatkan orang kedua (jemaah salat Jumat) sebagai pengacuan. Terdapat enam penggunaan pronomina kita dalam kalimat di atas semuanya mengacu pada bentuk yang sama yaitu khotib dan jemaah salat Jumat. Di samping itu, pengacuan yang digunakan dalam kalimat di atas bersifat endoforis yaitu unsur yang diacu berada di dalam teks.

Terdapat dua jenis pengacuan demonstratif yaitu pengacuan petunjuk tempat dan petunjuk waktu. Pengacuan demonstratif waktu dan tempat dapat diamati pada contoh berikut ini:

[6] Untuk itu agar kebaikan jiwa kita, kebaikan ibadah kita, kemurnian aqidah kita perlu kiranya yang baik kita lanjutkan sampai akhir hayat bukan hanya sekadar memperpanjang kebaikan tapi sekaligus meningkatkan apa yang pernah kita lakukan sehingga semakin lama kita hidup di dunia ini semakin sempurna cara kita mengabdi kepada Allah swt. dan dengan cara itulah maka kita berharap apabila kelak kita telah mendapat-kan izin untuk menghadap di mata Allah senantiasa khusnul khotimah. 
[7] Pada kesempatan kali ini akan saya sampaikan tiga hal yang akan merupakan amalan baik untuk menjaga agar kebaikan yang telah kita lakukan menjadi meningkat, kemungkinan ada salah dan keburukan yang terlanjur kita perbuat senantiasa menipis dan kita usahakan untuk dapat kita hilangkan.

Pada data [6] terdapat penggunaan pengacuan tempat berupa pemakaian kata "itu" dan "itulah" yang sifatnya endofora yang anaforis karena mengacu pada anteseden yang berada di sebelah kirinya, sedangkan pengacuan demonstrasi tempat terdapat pada penggunaan kata "di dunia ini" yang sifatnya endofora anaforis. Demikian pula contoh kutipan khotbah pada data [7] terlihat bahwa terdapat penggunaan pengacuan demonstratif waktu yang terlihat pada kata "pada kesempatan kali ini". Pengacuan ini bersifat endofora kataforis karena anteseden yang diacu berada di sebelah kanannya.

Substitusi adalah suatu unsur wacana yang bias diganti (disulih) dengan unsur wacana lain asalkan acuannya tetap sama. Terdapat empat jenis substitusi yaitu substitusi nominal, verbal, frasal, dan kausal, sedangkan dalam analisis khotbah ini hanya terdapat dua jenis yaitu substitusi nominal dan substitusi kausal. Penggunaan bentuk substisusi dapat dilihat dalam contoh berikut ini.

[8] Untuk itu agar kebaikan jiwa kita, kebaikan ibadah kita, kemurnian aqidah kita perlu kiranya yang baik kita lanjutkan sampai akhir hayat bukan hanya sekadar memperpanjang kebaikan tapi sekaligus meningkatkan apa yang pernah kita lakukan sehingga semakin lama kita hidup di dunia ini semakin sempurna cara kita mengabdi kepada Allah swt. dan dengan cara itulah maka kita berharap apabila kelak kita telah mendapatkan izin untuk menghadap di mata Allah senantiasa khusnul khotimah.

[9] Kaum muslimin sidang Jumat berbahagia, Hadirin sidang Jumat rakhimakumullah, Hadirin sidang Jumat yang berbahagia,

[10] Sesungguhnya orang-orang yang berkata, "Tuhan kami adalah Allah" kemudian mereka meneguhkan pendirian mereka

Dalam kutipan khotbah kalimat [8] di atas terdapat pemakaian kata "dengan cara itulah" yang merupakan bentuk substitusi kausal karena kata tersebut mengacu pada makna sebelumnya. Kemudian kalimat [9] terdapat tiga bentuk sapaan yang digunakan oleh khotib ketika berceramah namun bentuk pengacuan ketiganya adalah hal yang sama yaitu jemaah salat Jumat yang sekaligus penyimak khotbah. Substitusi kata sapaan tersebut barangkali untuk sedikit mengurangi ke-monoton-an sehingga dirasa penggunaan substitusi klausal dianggap lebih efektif. Berbeda halnya dengan kalimat [10] merupakan contoh kalimat yang menggunakan substitusi nominal karena yang diacu adalah nomina yaitu kata "orang-orang" disubstitusi dengan kata "mereka."

Elipsis merupakan pelesapan unsur bahasa yang maknanya telah diketahui sebelumnya berdasarkan konteksnya. Penggunaan bentuk elipsis dapat dilihat pada kalimat berikut ini.

[11] Untuk itu agar kebaikan jiwa kita, $\delta$ kebaikan ibadah kita, $\delta$ kemurnian aqidah kita perlu kiranya yang baik kita lanjutkan sampai akhir hayat bukan hanya sekadar memperpanjang kebaikan.

[12] Orang yang beristiqomah selalu kokoh dalam aqidah dan tidak goyang keimanannya dalam tantangan hidup. $\delta$ Sekalipun dihadapkan pada persoalan hidup, ibadah tidak ikut redup. Kantong kering atau tebal tetap memperhatikan haram dan halal.

Kalimat [11] terdapat pelesapan konjungsi agar sebagai bentuk efektivitas kalimat yang seharusnya pada kata yang bersimbol dibubuhi konjungsi "agar", sedangkan kalimat [12] terdapat pelesapan subjek yang seharusnya pada kata yang bersimbol dapat dibubuhi subjek "orang yang beristiqomah."

Konjungsi atau perangkaian adalah aspek yang menghubungkan satu bagian wacana dengan bagian lain baik berupa klausa, kalimat, maupun paragraf (alenia).

[13] Tiga hal tersebut yang pertama adalah istiqomah yaitu pokok dalam aqidah dan konsisten dalam beribadah.

[14] Nabi menjawab: Katakanlah aku telah beriman kepada Allah kemudian beristiqomahlah.

[15] Sekalipun dihadapkan pada persoalan hidup, ibadah tidak ikut redup. Kantong kering atau 
tebal tetap memperhatikan haram dan halal. Dicaci atau dipuji, sujud pantang berhenti. Sekalipun ia memiliki fasilitas kenikmatan, ia tidak tergoda untuk melaksanakan kemaksiatan.

Pada kalimat [13] terdapat pemakaian konjungsi adalah dan yaitu yang merupakan jenis konjungsi komplementatif, sedangkan kalimat [14] terdapat pemakaian konjungsi kemudian yang merupakan jenis konjungsi urutan (sekuensial), kemudian kalimat [15] konjungsi sekalipun merupakan jenis konjungsi konsesif, sedangkan konjungsi 'dan' atau 'untuk' merupakan jenis konjungsi penambahan (aditif).

Kepaduan wacana khotbah Jumat ini selain didukung oleh aspek gramatikal atau kohesi gramatikal juga didukung dengan adanya aspek leksikal atau kohesi leksikal. Kohesi leksikal dalam sebuah wacana dapat dibedakan menjadi enam macam, yaitu repetisi (pengulangan), sinonimi (padan kata), kolokasi (sanding kata), hiponimi (hubungan atas-bawah), antonimi (lawan kata, oposisi makna) dan ekuivalensi (kesepadanan bentuk) Sumarlam (2008: 27). Dalam khotbah Jumat ini keenam komponen tersebut dimanfaatkan dengan baik oleh sang khotib, kecuali kolokasi (sanding kata) yang nyaris tidak digunakan. Adapun penjelasannnya dapat dilihat pada uraian berikut.

Repetisi atau pengulangan adalah pengulangan satuan lingual (bunyi, suku kata, kata atau bagian kalimat) yang dianggap penting untuk memberikan tekanan dalam sebuah konteks yang sesuai. Dalam khotbah jumat ini khotib menyapa para hadirin dengan menggunakan frasa yang sejenis dan semakna. Kata sapaan digunakan untuk menghubungkan inti yang akan disampaikan pada tiap-tiap bagian. Sapaan khas yang digunakan khotib dapat dilihat pada frasa berikut:

[16] Kaum muslimin sidang Jumat berbahagia,

Hadirin sidang Jumat rakhimakumullah, Hadirin sidang Jumat yang berbahagia, Jemaah Jumat rakhimakumullah.

Sekilas, kutipan di atas bukanlah merupakan pengulangan, akan tetapi jika kita cermati empat frasa tersebut memiliki makna dan merujuk ke satu objek yang sama, yaitu orang-orang yang hadir dalam salat Jumat. Khotib menggunakan variasi kata yang berupa kaum muslimin, hadirin, dan jemaah untuk menimbulkan suasana yang berbeda, akan tetapi maknanya sama. Adapun kata-kata berbahagia, dan rakhimakumullah sebenarnya juga memiliki makna yang hampir sama. Orang yang dirahmati Allah (rakhimakumullah) tentunya dia juga orang yang bahagia. Dengan demikian keempat frase tersebut dapat dikatakan sama.

Pronomina persona adalah pronomina yang dipakai untuk mengacu pada orang (Hasan Alwi, 2003: 249). Khotib dengan jelas menggunakan pronomina persona kita yang diulang-ulang untuk menekankan inti pembicaraan kepada orang lain. Pronomina ini juga dimaksudkan untuk mengajak kepada semuanya untuk berbuat kebaikan. Lebih lanjut dijelaskan bahwa pronomina persona kita bersifat inklusif yang artinya pronomina ini mencakupi tidak saja pembicara atau penulis akan tetapi juga pendengar atau pembaca, dan mungkin pula pihak lain. Pengulangan pronomina yang dilakukan khotib dapat dilihat pada kalimat berikut:

[17] ...berbagai kenikmatan kepada kita semuanya...

...pemberian tersebut kita dapat...

Bahkan khotib tidak hanya menggunakan dan mengulang kata kita sekali dalam kalimat, akan tetapi pengulangan dilakukan beberapa kali. Hal tersebut dimaksudkan untuk mengajak dan lebih menekankan apa yang diinginkan. Misalnya pada kalimat berikut, kata kita diulang sebanyak 8 kali. [18] Untuk itu agar kebaikan jiwa kita, kebaikan ibadah kita, kemurnian aqidah kita, perlu kiranya yang baik kita lanjutkan sampai akhir hayat bukan hanya sekadar memperpanjang kebaikan tapi sekaligus meningkatkan apa yang pernah kita lakukan sehingga semakin lama kita hidup di dunia ini semakin sempurna cara kita mengabdi kepada Allah swt. dan dengan cara itulah maka kita berharap apabila kelak kita telah mendapatkan izin untuk menghadap di mata Allah senantiasa khusnul khotimah.

[19] Agar kita tetap tegar dan selamat dalam berbagai gelombang kehidupan tidak bisa tidak paling tidak kita harus berusaha, kita harus memiliki dan kita harus melakukan tiga hal yang telah saya sebutkan tadi yaitu istiqomah, istigfar, istikharah. 
Dalam khotbah ini, khotib tidak banyak menggunakan kata-kata yang bersinonim. Akan tetapi bukan berarti kata-kata yang bersinonim tidak ditemukan dalam khotbah tersebut. Contoh penggunaan kata bersinonim yang dapat ditemukan adalah pada kutipan kalimat berikut:

[20] Sekali pun menahan ucapan itu terasa berat, tetapi jika ucapan itu benar dan baik maka katakanlah jangan ditahan, sebab lidah kita bisa menjadi lemas untuk bisa meneriakkan kebenaran dan keadilan serta menegakkan amar ma'ruf nahi munkar.

[21] ...banyak orang berbicara tanpa berbijak pada data-data yang benar dan bertindak sekehendaknya tanpa mengindahkan etika agama.

Kata meneriakkan dengan kata berbicara memiliki makna yang hampir sama yaitu melafalkan bunyi bahasa dengan menggunakan oral atau mulut.

Hubungan atas-bawah atau hiponimi dalam khotbah tersebut dapat diidentifikasi sebagai berikut:

[22] Puji syukur senantiasa kita panjatkan kehadirat Allah swt. yang telah berkenan memberikan berbagai kenikmatan kepada kita semuanya sehingga atas pemberian tersebut kita dapat melaksanakan aktivitas seperti yang kita inginkan dan dapat pula kita sampaikan rasa syukur kita kehadirat Allah swt. dengan memperbanyak ibadah dan dzikir kepada Allah.

Kata ibadah merupakan kata atasan untuk kata dzikir. Ibadah memiliki arti yang lebih luas sedangkan dzikir merupakan bagian dari ibadah. Macam-macam ibadah misalnya salat, zakat, membaca Alquran, dan berdzikir.

Antonim atau makna yang berlawanan sering digunakan khotib untuk membandingkan dua hal yang berbeda atau berlawanan. Beberapa contoh antonim yang digunakan dapat dilihat pada kutipan berikut.

[23] Mudah-mudahan yang demikian senantiasa menjadi sebab menjaga agar kebaikan dari Allah yang telah kita terima dan kita menfaatkan untuk membersihkan diri kita dari kejahatan, dari keburukan sehingga dapat melepaskan kita dari belenggu yang dimurkai oleh Allah swt.
Ekuivalensi (kesepadanan bentuk) juga ditemukan pada teks tersebut. Beberapa temuan itu dapat dilihat pada kutipan berikut:

[24] Mungkin itu hanya jadi kajian kecil dari upaya kita untuk berusaha menyempurnakan agama Islam yang kita ikuti ajarannya dan belum juga mencapai kesempurnaan karena kemungkinan untuk lebih sempurna sesuai apa yang diajarkan dalam Alquran mungkin kita masih jauh.

\section{Analisis Makrostruktural}

Secara makrostruktural, analisis wacana menitikberatkan pada garis besar susunan wacana itu secara global, untuk memahami teks secara keseluruhan di samping memperhatikan keterkaitan antarepisode, paragraf atau bahkan antarbab juga dipertimbangkan pelatarbelakangan (background) dan pelatardepanan (foreground) (Djajasudarma, 2009: 4). Pendekatan makrostruktural dapat mengikuti struktur tekstual, sistem leksis, dan konteks. Adapun yang dimaksudkan konteks secara makrostruktural adalah konteks situasi dan konteks struktural.

Dalam analisis ini, tidak akan dibicarakan terlalu dalam hingga tataran latar belakang, latar depan atau bahkan konteks yang diciptakan oleh khotib. Hal yang dianalisis hanya berkaitan dengan struktur teks atau alur yang digunakan khotib dalam menyampaikan uraian khotbah. Secara garis besar alur yang digunakan dalam khotbah tersebut dapat diuraikan seperti berikut. Pertama, Pembukaan; Layaknya penceramah atau khotib yang lain, dalam khotbah Jumat ini khotib juga menggunakan sapaan dan pembukaan terlebih dahulu dalam menyampaikan materi khotbah. Dalam pembukaan ini khotib mengajak para hadirin untuk senantiasa mensyukuri apa yang telah diberikan oleh Allah swt. kepada manusia karena atas karunianya manusia dapat melakukan segala aktivitasnya. Kedua, Isi atau Pembahasan; Khotib tidak langsung menyampaikan apa yang menjadi pokok pembicaraan, akan tetapi menggunakan analogi sederhana untuk membuka pikiran hadirin yang ada. Hal tersebut dapat dilihat pada kalimat pertama yang menggunakan peristiwa alam sebagai gambaran hidup manusia. Kontradiktif peristiwa alam seperti halnya siang dan malam juga digunakan untuk 
menggambarkan kehidupan manusia yang hampir sama dengan kejadian tersebut. Setelah itu, barulah khotib menyampaikan isi materi. Tampak pada kalimat "Pada kesempatan kali ini akan saya sampaikan tiga hal...". Selanjutnya khotib menyampaikan materi dengan penalaran umum khusus. Khotib menjabarkan satu per satu inti pembicaraannya dengan dasar-dasar yang ada dalam Alquran dan hadis. Ketiga, Penutup; Pada bagian ini khotib menarik kesimpulan dan memberikan penguatan agar hadirin mau melaksanakan apa yang telah disampaikan. Keempat, Doa; Pada bagian ini, khotib tidak mengulangi apa yang telah disampaikan pada bagian yang pertama, layaknya khotbah yang ada yaitu khotbah pertama sebagai pemberian materi dan khotbah kedua sebagai penguatan materi yang ada pada khotbah pertama. Dalam khotbah ini, khotib menggunakan khotbah kedua untuk membacakan doa. Doa di sini merupakan rangkaian khotbah yang lazim dilakukan saat salat Jumat.

Khotbah merupakan salah satu sarana yang digunakan umat Islam yang bertujuan untuk mengajak masyarakat untuk berbuat baik dan mencegah perbuatan buruk (sarana dakwah). Agar dapat menarik simpati dari jemaah atau orang yang menyimak khotbah, diperlukan sebuah keterampilan berbicara yang baik. Istilah untuk menarik massa malalui keterampilan berbicara dimaknai sebagai retorika. Retorika merupakan seni dalam berbicara. Berbicara berarti mengucapkan kata atau kalimat kepada seseorang atau sekelompok orang, untuk mencapai tujuan tertentu, misalnya memberi informasi atau motivasi. Selaras dengan pendapat tersebut Maidar G. Arsjad dan Mukti US (1988: 7) memberi batasan mengenai retorika yaitu merupakan teori dan praktik kemahiran berbahasa, baik lisan maupun tulis. Retorika bertujuan menerangkan kaidah-kaidah yang menjadi landasan dari menulis dan bertutur untuk mempengaruhi sikap dan perasaan seseorang. Retorika membicarakan prinsip-prinsip yang fundamental untuk menyusun sebuah wacana.

Berdasarkan pendapat ahli di atas maka khotbah Jumat dapat dikatakan sebagai sebuah retorika sebab khotbah Jumat melibatkan kemampuan berbicara (wacana lisan) untuk mengajak jemaah melakukan suatu hal. Dalam hal ini khotib yang mengajak jemaahnya untuk mengamalkan materi yang telah ia sampaikan.

Retorika yang digunakan oleh pelibat wacana dalam peristiwa komunikasi pada umumnya menggunakan pola retorika yang terstruktur, diawali dengan pembukaan (salam pembuka), dilanjutkan inti pembicaraan, kemudian diakhiri dengan penutup. Demikian pula dengan khotbah Jumat yang memiliki pola struktur retorika yang khas meskipun pada dasarnya memiliki konsep dasar yang sama dengan bentuk retorika-retorika yang lain.

Salam pembuka yang dilakukan oleh khotib pada umumnya sama yaitu mengucapkan salam assalâmu 'alaikum wa rahmatullâhi wa barakâtuh yang dilanjutkan dengan menyapa jemaah salat Jumat. Yang seringkali berbeda adalah format pembukaaan yang bervariasi namun strukturnya tetap sama yaitu berupa selawat seperti pada kutipan khotbah Jumat.

Setelah menyampaikan salam pembuka dan pembukaan, khotib lalu menyampaikan materi khotbah Jumat. Dalam khotbah yang dianalisis ini, khotib mengangkat tema mengenai amalanamalan yang dapat menjadi dan meningkatkan kebaikan. Adapun topik pembicaraannya mengenai pengertian istighfar, istiqomah, dan istikharah yang disertai dengan kutipan-kutipan hadis dan ayat Alquran.

Sesuai dengan tujuan khotbah, yakni mengajak jemaah untuk berbuat baik dan mencegah perbuatan buruk, maka retorika penutup merupakan bagian yang penting dalam sebuah khotbah. Retorika ini biasanya berupa pesan, ajakan, dan harapan, maupun kesimpulan dari materi khotbah yang telah diuraikan. Berikut ini adalah retorika penutup dari seorang khotib untuk mengajak jemaahnya agar mengamalkan apa yang telah disampaikan khotib tersebut.

[25] Mungkin itu hanya jadi kajian kecil dari upaya kita untuk berusaha menyempurnakan agama Islam yang kita ikuti ajarannya dan belum juga mencapai kesempurnaan karena kemungkinan untuk lebih sempurna sesuai apa yang diajarkan dalam Alquran mungkin kita masih jauh. Untuk itu, mudah-mudahan Allah memberi kekuatan kepada kita untuk menata masa depan dengan keimanan dan 
rahmat-Nya yang berlimpah. Allahuma Amin.

Setelah penutup, dalam khotbah Jumat bukan berarti telah selesai rangkaian tahapan retorika tersebut, sebab masih ada tahapan khotbah kedua yang merupakan pembacaan doa. Sebelum khotbah kedua biasanya memberi jeda sejenak sebagai tanda bahwa akan dimulainya khotbah kedua. Adanya khotbah kedua inilah yang merupakan ciri khas khotbah Jumat yang berbeda dengan khotbah-khotbah lainnya. Selanjutnya baru dilanjutkan dengan salam penutup seperti pada contoh berikut:

[26] Aqullu qolihadza wastagfirullah innaka huwal walimanakum fastagfirullah ghofururakhim. Wassalamu'alaikum warakhmatullahi wabarakatuh.

Konteks adalah aspek-aspek internal teks dan segala sesuatu yang secara eksternal tidak hanya melingkupi sebuah teks (Sumarlam, 2008: 14). Hal ini berarti tidak hanya hal-hal yang berkaitan dengan aspek kebahasaan saja yang mempengaruhi sebuah makna tetapi juga aspek nonkebahasaannya. Soeseno Kartomihardjo (1993:26-28) menyatakan bahwa terdapat beberapa jenis konteks yaitu konteks yang berhubungan dengan partisipan; tempat dan waktu; saluran yang digunakan; kode yang digunakan; bentuk pesan beserta isinya; peristiwa dengan sifat-sifat yang khusus dan nada pembicaraan.

Konteks yang berkaitan dengan partisipan dalam suatu interaksi yang terdiri dari penyapa, pesapa, dan pendengar memegang peranan yang sangat penting. Dalam hal ini terlihat dengan adanya hubungan antara khotib dan jemaah salat Jumat. Hubungan ini tentu saja merupakan bahan pertimbangan khotib dalam pemilihan bahasa agar materi yang disampaikan dapat diterima dengan baik oleh penyimak khotbah (jemaah salat Jumat).

Konteks berhubungan dengan tempat dan waktu. Pelaksanaan khotbah Jumat pada umumnya dilaksanakan di sebuah masjid yang selanjutnya akan digunakan untuk melaksanakan ibadah salat Jumat. Mengenai waktu pelaksanaan khotbah selalu dilaksanakan di hari Jumat menjelang pelaksanaan salat Jumat. Dengan kondisi semacam ini, pelaksanaan khotbah merupakan kegiatan yang termasuk kegiatan formal. Konteks juga berkaitan dengan topik. Dengan menggunakan topik tertentu, suatu interaksi dapat berjalan lancar. Ciri khas sebuah retorika adalah memiliki pola terstruktur dalam penyampaiannya. Demikian halnya dalam sebuah khotbah, yang memiliki pola penyampaian yang terstruktur. Termasuk di dalamnya penentuan topik sehingga alur penyampaian khotbah tidak tergeser dari kerangka yang telah dirancang sebelumnya. Konteks berikutnya adalah saluran yang digunakan. Khotbah Jumat dilaksanakan secara tatap muka (face to face) langsung antara khotib dan jemaah salat Jumat yang sifatnya searah. Jadi, tidak ada timbal balik antara khotib dengan penyimak khotbah Jumat. Hal ini berarti saluran yang digunakan berupa penyampaian secara lisan. Konteks selanjutnya adalah kode yang digunakan. Kegiatan khotbah Jumat yang merupakan kegiatan formal, maka penggunaan ragam bahasa yang tepat adalah ragam bahasa baku yaitu bahasa Indonesia agar dipahami oleh semua jemaah. Penggunaan ragam bahasa dialek daerah kadangkala membuat jemaah kurang mengerti makna pesan yang disampaikan karena jemaah bersangkutan tidak paham dengan dialek daerah tertentu. Meskipun adakalanya penyisipan ragam dialek daerah bisa menjadi salah satu daya tarik dalam penyampaian khotbah. Konteks selanjutnya terdapat di dalam bentuk pesan beserta isinya. Bagaimana seorang komunikator mampu atau terampil dalam menyampaikan pesan sehingga dapat diterima dengan baik oleh komunikan. Contoh nyata dalam kegiatan khotbah adalah penggunaan bahasa yang sederhana sehingga mudah diterima oleh penerima khotbah. Dengan kata lain, melalui penggunaan dialekdialek daerah pesan yang disampaikan oleh khotib dirasakan oleh begitu dekat dengan kehidupan dengan penerima pesan. Konteks selanjutnya adalah peristiwa yang sifat-sifatnya khusus. Khotbah Jumat merupakan sebuah peristiwa yang melibatkan penggunaan bahasa ketika terjadi proses penyampaian pesan dari khotib kepada jemaahnya. Khotbah Jumat memiliki sifat-sifat khusus dibanding khotbah lainnya yaitu hanya dilaksanakan khusus pada hari Jumat saja dan pelaksanaannya berlangsung secara khidmat. Konteks berikutnya nada pembicaraan yang dapat berupa nada pembicaraan serius, sinis, ajakan, 
dan lain-lain. Dalam khotbah Jumat digunakan nada pembicaraan yang santun, serius, dan bersifat ajakan. Pertimbangan penggunaan nada pembicaraan tersebut tentu saja tidak lepas dari tujuan utama khotbah yaitu mengajak jemaah berbuat baik dan mencegah perbuatan tercela. Oleh karena itu, pemilihan nada pembicaraan dalam khotbah harus diperhatikan sungguhsungguh.

\section{Simpulan dan Saran Simpulan}

Khotbah Jumat merupakan suatu wacana karena mempunyai syarat sebagai sebuah wacana yang mempunyai struktur dengan diikuti oleh maksud dan tujuan. Khotbah Jumat juga tersusun atas unsur-unsur bahasa yang mempunyai kohesi dan koherensi. Khotbah Jumat termasuk dalam wacana lisan karena tuturan yang disampaikan penutur atau khotib langsung disampaikan tanpa perantara kepada mitra tutur atau jemaah salat Jumat. Oleh karena hal tersebut maka khotbah Jumat dapat dikaji secara mikrostruktural maupun makrostruktural.

Analisis dari aspek mikrostruktural dapat disimpulkan bahwa yang dianalisis adalah aspek gramatikal dan aspek leksikal. Dalam aspek gramatikal, khotbah Jumat yang dikaji mempunyai unsur referensi, substitusi, elipsis, dan konjungsi. Adapun dari aspek leksikal, khotbah Jumat mengadung unsur repitisi, sinonimi, hiponimi, antonimi, dan ekuivalensi. Unsur kohesi dan koherensi juga dimiliki khotbah Jumat sebagai sebuah wacana dalam kajian mikrostruktural.
Analisis makrostruktural yang berkaitan dengan analisis susunan wacana secara global. Artinya bahwa unsur kultural atau kebudayaan sangat mempengaruhi wacana dalam khotbah Jumat, terutama unsur budaya Jawa karena khotbah Jumat yang dianalisis berlangsung di Kota Surakarta yang mempunyai budaya Jawa sangat dominan. Analisis makrostruktural juga berkaitan dengan konteks yang terdiri dari partisipan, tempat dan waktu, saluran yang digunakan, kode yang digunakan, bentuk pesan beserta isinya, peristiwa dengan sifat, dan nada pembicaraan.

\section{Saran}

Saran untuk khotib adalah berkaitan dengan materi khotbah harus disesuaikan dengan keadaan jemaah dan lingkungan masjid. Apabila masjid terletak di lingkungan pendidikan maka materi khotbah disesuaikan dengan permasalahan pendidikan. Hal ini berkaitan dengan tujuan utama khotbah Jumat, yaitu mengajak jemaah untuk meningkatkan takwa kepada Allah swt.. Bahasa pengantar khotbah Jumat juga harus menarik dan mudah dipahami oleh jemaah. Khotbah Jumat merupakan tuturan lisan sehingga khotib harus pandai beretorika agar jemaah tertarik dengan khotbah yang disampaikan. Dengan materi khotbah yang dekat dengan permasalahan jemaah diharapkan lebih mendekatkan hubungan antara khotib dan jemaah. Adapun saran untuk jemaah adalah selalu memperhatikan materi khotbah karena selain sebagai sebuah ibadah, di dalam khotbah Jumat banyak hal-hal penting yang disampaikan khotib dan dapat berguna dalam kehidupan.

\section{Pustaka Acuan}

Alwi, Hasan (ed). 2003. Tata Bahasa Baku Bahasa Indonesia, Edisi Ketiga. Jakarta: Balai Pustaka. Baal-Baki, R. 1993. Al-Maurid: Qamus 'Araby-Injilizi: Darul-'IIm lil-malayin.

Brown, Gillian dan George Yule. 1996. Discourse Analysis. Cambridge: Cambridge University Press. Crystal, David. 1987. The Cambridge Encyclopedia of Language. Cambridge: Cambridge University Press.

Djajasudarma, Fatimah. 2009. Wacana: Pemahaman dan Hubungan Antarunsur. Bandung: Eresco.

Dwiraharjo, Maryono. 2001. Bahasa Jawa Krama. Surakarta: Pustaka Cakra Bekerjasama dengan Yayasan Adikarya IKAPI dan The Ford Foundation.

Edmondson, Willis. 1981. Spoken Discourse: A Model for Analysis. London: Longman.

Halliday, MAK, Ruqaiya Hasan. 1994. Bahasa, Konteks, dan Teks. Terjemahan Asrudin Barori Tou. Yogyakarta: Gadjah Mada University Press. 
Harimurti, Kridalaksana. 2008. Kamus Linguistik. Jakarta: P.T. Gramedia.

Lindlof, Thomas R. 1994. Qualitative Communication Research Methods. Thousand Oaks: SAGE Publiser.

Markhamah. 2001. Etnik Cina: Kajian Linguistis Kultural. Surakarta: Universitas Muhammadiyah

Surakarta Press.

Ma'ruf, Amir. 1999. "Wacana Khotbah Jumat: Studi Kasus Empat Masjid di Yogyakarta". Yogyakarta:

Universitas Gadjah Mada. (Tesis).

Moeliono, Anton M. (ed.). 2008. Kamus Besar Bahasa Indonesia Edisi Keempat. Jakarta: Kementerian Pendidikan Nasional

Rani, Abdul, Bustanul Arifin, dan Martutik. 2006. Analisis Wacana: Sebuah Kajian Bahasa dalam Pemakaian. Malang: Bayumedia Publishing.

Sabiq, As. Tt. Fiqhus- Sunnah. Jilid I dan II Jidah; Maktabatul-Khidmatil-Khadisah.

Saddhono, Kundharu. 2009. Oreng Madure dan Wong Solo: Fenomena Integrasi Linguistik Kultural. Surakarta: Sebelas Maret University Press dan Departemen Pendidikan Nasional

Saddhono, Kundharu. 2011. "Wacana Khotbah Jumat di Kota Surakarta: Sebuah Kajian Sosiopragmatik". Yogyakarta: Program Pascasarjana Universitas Gadjah Mada (Disertasi)

Schiffrin, Deborah. 1984. Approaches to Discourse. Oxford: Blackwell.

Subroto, Edi. 2009. Pengantar Metode Penelitian Linguistik Struktural. Surakarta: UNS Press.

Sudaryanto. 1995. Linguistik: Identitasnya, Cara Penanganan Obyeknya, dan Hasil Kajiannya. Yoyakarta: Duta Wacana University Press.

Sutopo, H. B. 1996. Metodologi Penelitian Kualitatif: Metodologi Penelitian untuk Ilmu-ilmu Sosial dan Budaya. Surakarta: Universitas Sebelas Maret.

Suwandi, Sarwiji. 2003. "Kohesi dalam Bahasa Indonesia" dalam Linguistik Indonesia. Jakarta: Masyarakat Linguistik Indonesia Bekerjasama dengan Yayasan Obor Indonesia.

Sumarlam (ed). 2008. Teori dan Praktik Analisis Wacana Cetakan Keempat. Surakarta: Pustaka Cakra. Syam, Yunus Hanis. 2003. Titian Menuju Takwa. Yogyakarta: Cahaya Hikmah.

Tarigan, Henry Guntur. 2009. Pengajaran Wacana. Bandung: Angkasa.

Kartomihardjo, Soeseno. 1993. "Analisis Wacana dengan Penerapannya pada Beberapa Wacana". PELBA 6. Jakarta: Lembaga Bahasa Unika Atmajaya. 